\title{
Iridium(III) Complexes with Orthometalated Quinoxaline Ligands: Subtle Tuning of Emission to the Saturated Red Color
}

\author{
Fu-Ming Hwang, ${ }^{\dagger}$ Hsing-Yi Chen,${ }^{\dagger}$ Po-Shen Chen,${ }^{\dagger}$ Chao-Shiuan Liu,${ }^{\dagger}$ Yun Chi, ${ }^{*},{ }^{\dagger}$ Ching-Fong Shu, ${ }^{*, \neq}$ \\ Fang-ly Wu, ${ }^{\ddagger}$ Pi-Tai Chou, ${ }^{*} \S$ Shie-Ming Peng, ${ }^{\S}$ and Gene-Hsiang Lee $\$$ \\ Department of Chemistry, National Tsing Hua University, Hsinchu 300, Taiwan, Department of \\ Applied Chemistry, National Chiao Tung University, Hsinchu 300, Taiwan, and Department of \\ Chemistry and Instrumentation Center, National Taiwan University, Taipei 106, Taiwan
}

Received August 3, 2004

\begin{abstract}
Rational design and syntheses of four iridium complexes (1-4) bearing two substituted quinoxalines and an additional 5-(2-pyridyl) pyrazolate or triazolate as the third coordinating ligand are reported. Single-crystal X-ray diffraction studies of 1 reveal a distorted octahedral geometry, in which two dpqx ligands adopt an eclipse configuration, for which the quinoxaline $\mathrm{N}$ atoms and the $\mathrm{C}$ atoms of orthometalated phenyl groups are located at the mutual transand cis-positions, respectively. The lowest absorption band for all complexes consists of a mixture of heavy-atom $\operatorname{Ir}(I I I)$-enhanced ${ }^{3} \mathrm{MLCT}$ and ${ }^{3} \pi \pi^{*}$ transitions, and the phosphorescent peak wavelength can be fine-tuned to cover the spectral range of $622-649 \mathrm{~nm}$ with high quantum efficiencies. The cyclic voltammetry was measured, showing a reversible, metal-centered oxidation with potentials at $0.76-1.03 \mathrm{~V}$, as well as two reversible reduction waves with potentials ranging from -1.61 to $-2.06 \mathrm{~V}$, attributed to the sequential addition of two electrons to the more electron-accepting heterocyclic portion of two distinctive cyclometalated $\mathrm{C} \wedge \mathrm{N}$ ligands. Complex 1 was used as the representative example to fabricate the red-emitting PLEDs by blending it into a PVK-PBD polymer mixture. The devices exhibited the characteristic emission profile of 1 with peak maxima located at $640 \mathrm{~nm}$. The maximum external quantum efficiency was $3.15 \%$ ph/el with a brightness of $1751 \mathrm{~cd} / \mathrm{m}^{2}$ at a current density of $67.4 \mathrm{~mA} / \mathrm{cm}^{2}$, and the maximum brightness of $7750 \mathrm{~cd} / \mathrm{m}^{2}$ was achieved at the applied voltage of $21 \mathrm{~V}$ and with $\mathrm{CIE}$ coordinates of $(0.64,0.31)$.
\end{abstract}

Organometallic complexes possessing a third-row transition-metal element are crucial for the fabrication of highly efficient organic light-emitting diodes (OLEDs). ${ }^{1}$ The strong spin-orbit coupling induced by a heavy-metal ion such as iridium(III) promotes an efficient intersystem crossing from the singlet to the triplet excited-state manifold, which then facilitates strong electroluminescence by the harnessing of both singlet and triplet excitons after the initial charge recombination. Because internal phosphorescence quantum efficiency $\left(h_{\text {int }}\right)$ of as high as $\sim 100 \%$ could theoretically be

* Authors to whom correspondence should be addressed. E-mail: ychi@mx.nthu.edu.tw (Y.C.); shu@cc.nctu.edu.tw (C.-F.S.); chop@ntu.edu.tw (P.-T.C.).

National Tsing Hua University.

$\doteqdot$ National Chiao Tung University.

$\S$ National Taiwan University.

(1) (a) Baldo, M. A.; O’Brien, D. F.; You, Y.; Shoustikov, A.; Sibley, S.; Thompson, M. E.; Forrest, S. R. Nature 1998, 395, 151. (b) Baldo, M. A.; Thompson, M. E.; Forrest, S. R. Pure Appl. Chem. 1999, 71, 2095. (c) Gong, X.; Ostrowski, J. C.; Bazan, G. C.; Moses, D.; Heeger, A. J. Appl. Phys. Lett. 2002, 81, 3711.

1344 Inorganic Chemistry, Vol. 44, No. 5, 2005 achieved, these heavy-metal-containing emitters would be superior to their fluorescent counterparts in future OLED applications. $^{2}$ As a result, there is a continuous trend of shifting research endeavors to these heavy transition metal complexes.

Moreover, since the manufacture of a full color display requires the usage of emitters with all three primary colors, i.e., blue, green, and red, rationally tuning the emission wavelength of heavy-metal phosphorescent emitters over the

(2) (a) Adachi, C.; Baldo, M. A.; Thompson, M. E.; Forrest, S. R. J. Appl. Phys. 2001, 90, 5048. (b) Ikai, M.; Tokito, S.; Sakamoto, Y.; Sduanuzuki, T.; Taga, Y.; Appl. Phys. Lett. 2001, 79, 156. (c) Tokito, S.; Iijima, T.; Tsuzuki, T.; Sato, F. Appl. Phys. Lett. 2003, 83, 2459. (d) Lo, S.-C.; Namdas, E. B.; Burn, P. L.; Samuel, I. D. W. Macromolecules 2003, 36, 9721. (e) Kwong, R. C.; Nugent, M. R.; Michalski, L.; Ngo, T.; Rajan, K.; Tung, Y.-J.; Weaver, M. S.; Zhou, T. X.; Hack, M.; Thompson, M. E.; Forrest, S. R.; Brown, J. J. Appl. Phys. Lett. 2002, 81, 162. (f) He, G.; Chang, S.-C.; Chen, F.-C.; Li, Y.; Yang, Y. Appl. Phys. Lett. 2002, 81, 1509. (g) Lee, C.-L.; Lee, K. B.; Kim, J.-J. Appl. Phys. Lett. 2000, 77, 2280. (h) Chen, C.-T. Chem. Mater. 2004, 16, 4389. Published on Web 02/04/2005 
entire visible range has emerged as an important ongoing research task. ${ }^{3}$ In contrast to the well-developed green phosphorescent materials, the design and synthesis of the red emitters is intrinsically more difficult because their luminescent quantum yields tend to be lower due to the smaller energy gap, implying that the red emitters could be prone to poor illumination efficiencies. ${ }^{2}$ Despite this limitation, reports on the red-emitting complexes with the Os(II) ${ }^{4}$ and $\mathrm{Pt}(\mathrm{II})^{5}$ elements have been documented in the literature. Unfortunately, to our knowledge, more generalized, systematic approaches, which allow a lucid prediction of the emission color and illumination quantum efficiency, have not yet been well established. Progress, to a certain extent, still relies on precedent experiences or certain serendipitous discoveries.

In this paper, we report a systematic design, synthesis, and characterization of red-emitting Ir(III)-containing complexes via judicious variation of ligands, for which, on one hand, the high rigidity of the ligand framework would significantly reduce the nonradiative transition. On the other hand, the energies of $\pi \pi^{*}$ or MLCT manifolds, i.e., the energy gap between the ground and the lowest excited states, can be effectively reduced either by substituting the nitrogen atom with a less electronegative carbon atom or extending the $\pi$-electron delocalization of the aromatic ligand chromophore, giving emitters with the saturated red color.

\section{Experimental Section}

General Experiments. 2,3-Bis(4-fluorophenyl)quinoxaline, (bfqx)H, was obtained from direct condensation of 1,2-phenylenediamine and 4,4'-difluorobenzil in refluxing ethanol, ${ }^{6}$ while 3 -(trifluoromethyl)-5-(2-pyridyl)pyrazole, (fppz)H, 3-tert-butyl-5-(2pyridyl)pyrazole, (bppz)H, and 3-(trifluoromethyl)-5-(2-pyridyl)triazole, (fptz)H, were prepared using methods described in the literature. ${ }^{7}$ The reactions were monitored by TLC with Merck precoated glass plates $\left(0.20 \mathrm{~mm}\right.$ with fluorescent indicator $\left.\mathrm{UV}_{254}\right)$. Compounds were visualized with UV light irradiation at 254 and $365 \mathrm{~nm}$. Column chromatography was carried out using silica gel from Merck (230-400 mesh). Mass spectra were obtained on a JEOL SX-102A instrument operating in electron impact (EI) mode or fast atom bombardment (FAB) mode. ${ }^{1} \mathrm{H}$ and ${ }^{13} \mathrm{C}$ NMR spectra

(3) Grushin, V. V.; Herron, N.; LeCloux, D. D.; Marshall, W. J.; Petrov, V. A.; Wang, Y. Chem. Commun. 2001, 1494.

(4) (a) Bernhard, S.; Gao, X.; Malliaras, G. G.; Abruna, H. D. Adv. Mater. 2002, 14, 433. (b) Carlson, B.; Phelan, G. D.; Kaminsky, W.; Dalton, L.; Jiang, X. Z.; Liu, S.; Jen, A. K.-Y. J. Am. Chem. Soc. 2002, 124 , 14162. (c) Kim, J. H.; Liu, M. S.; Jen, A. K.-Y.; Carlson, B.; Dalton, L. R.; Shu, C.-F.; Dodda, R. Appl. Phys. Lett. 2003, 83, 776. (d) Tung, Y.-L.; Wu, P.-C.; Liu, C.-S.; Chi, Y.; Yu, J.-K.; Hu, Y.-H.; Chou, P.-T.; Peng, S.-M.; Lee, G.-H.; Tao, Y.; Carty, A. J.; Shu, C.-F.; Wu, F.-I. Organometallics 2004, 23, 3745. (e) Su, H.-J.; Wu, F.-I.; Shu, C.-F.; Tung, Y.-L.; Chi, Y.; Lee, G.-H. J. Polym. Sci., Part A: Polym. Chem. 2005, in press. (f) Tung, Y.-L.; Lee, S.-W.; Chi, Y.; Tao, Y.T.; Chien, C.-H.; Cheng, Y.-M.; Chou, P.-T.; Peng, S.-M.; Liu, C.-S. J. Mater. Chem. 2005, 15, 460.

(5) (a) Kwong, R. C.; Sibley, S.; Dubovoy, T.; Baldo, M.; Forrest, S. R.; Thompson, M. E. Chem. Mater. 1999, 11, 3709. (b) Che, C.-M.; Hou, Y.-J.; Chan, M. C. W.; Guo, J.; Liu, Y.; Wang, Y. J. Mater. Chem. 2003, 13, 1362.

(6) Steel, P. J.; Caygill, G. B. J. Organomet. Chem. 1990, 395, 359.

(7) (a) Thiel, W. R.; Eppinger, J. Chem.-Eur. J. 1997, 3, 696. (b) Singh, S. P.; Kumar, D.; Jones, B. G.; Threadgill, M. D. J. Fluorine Chem. 1999, 94, 199. (c) Kubota, S.; Uda, M.; Nakagawa, T. J. Heterocycl. Chem. 1975, 12, 855. (d) Funabiki, K.; Noma, N.; Kuzuya, G.; Matsui, M.; Shibata, K. J. Chem. Res., Miniprint 1999, 1301. were recorded on a Varian INOVA-500 instrument; chemical shifts are quoted with respect to the internal standard TMS for ${ }^{1} \mathrm{H}$ and ${ }^{13} \mathrm{C}$ NMR data. Elemental analysis was carried out with a Heraeus CHN-O Rapid Elementary Analyzer.

Spectroscopic and CV Measurements. Steady-state absorption and emission spectra were recorded with a Hitachi (U-3310) spectrophotometer and an Edinburgh (FS920) fluorometer, respectively. Both the wavelength-dependent excitation and emission response of the fluorometer had been calibrated. Lifetime studies were performed with an Edinburgh FL 900 photon-counting system with a hydrogen-filled/or a nitrogen lamp as the excitation source. Data were analyzed using the nonlinear least-squares procedure in combination with an iterative convolution method. The emission decays were analyzed by the sum of exponential functions, which allows partial removal of the instrument time broadening and consequently renders a temporal resolution of $\sim 200 \mathrm{ps}$. DCM was used as a reference, assuming a quantum yield $\Phi_{\mathrm{f}}=0.44 .{ }^{8}$ to determine luminescence quantum yields of the studied compounds in solution. Solution samples were degassed by three freezepump-thaw cycles. The resulting luminescence was acquired by an intensified charge-coupled detector. Cyclic voltammetry (CV) and differential pulse voltammetry (DPV) measurements were performed using a BAS $100 \mathrm{~B} / \mathrm{W}$ electrochemical analyzer. The oxidation and reduction measurements were recorded using Pt wire and $\mathrm{Au}$ disk coated with $\mathrm{Hg}$ as working electrodes, respectively, in anhydrous $\mathrm{CH}_{2} \mathrm{Cl}_{2}$ and anhydrous THF containing $0.1 \mathrm{M} \mathrm{TBAPF}_{6}$ as the supporting electrolyte, at the scan rate of $50 \mathrm{mV} \mathrm{s}^{-1}$. The potentials were measured against an $\left.\mathrm{Ag} / \mathrm{Ag}^{+}(0.01 \mathrm{M} \mathrm{AgNO})_{3}\right)$ reference electrode with ferrocene as the internal standard.

Preparation of $\left[(\mathbf{d p q} \mathbf{x})_{2} \mathbf{I r C l}\right]_{2}$. The chloride-bridged complex $\left[(\mathrm{dpqx})_{2} \mathrm{IrCl}\right]_{2}$ was synthesized according to the method reported by Nonoyama, ${ }^{9}$ involving treatment of $\mathrm{IrCl}_{3} \cdot 3 \mathrm{H}_{2} \mathrm{O}(1.0 \mathrm{~g}, 2.84$ $\mathrm{mmol})$ with 2,3-diphenylquinoxaline, (dpqx)H (2.4 g, $8.51 \mathrm{mmol})$, in 2-methoxyethanol $(30 \mathrm{~mL})$ for $48 \mathrm{~h}$. After the cooling of the reaction mixture, the solution was treated with water $(30 \mathrm{~mL})$ to induce precipitation of a brick red solid. The solid was then filtered off, washed with diethyl ether, and dried under vacuum (1.93 g, $1.22 \mathrm{mmol}, 86 \%$ ).

Preparation of $\left[(\mathbf{d p q x})_{2} \operatorname{Ir}(\mathbf{f p p z})\right](\mathbf{1})$. A mixture of $\left[(\mathrm{dpqx})_{2} \mathrm{IrCl}\right]_{2}$ (350 mg, $0.22 \mathrm{mmol}$ ), 3-(trifluoromethyl)-5-(2-pyridyl)pyrazole ((fppz)H, $130 \mathrm{mg}, 0.61 \mathrm{mmol})$, and $\mathrm{Na}_{2} \mathrm{CO}_{3}(120 \mathrm{mg}, 1.13 \mathrm{mmol})$ in 2-methoxyethanol $(30 \mathrm{~mL})$ was heated to reflux for $12 \mathrm{~h}$. Excess of water was added after cooling the solution to RT (room temperature). The precipitate was collected by filtration and washed with anhydrous ethanol $(10 \mathrm{~mL})$, followed by diethyl ether $(10 \mathrm{~mL})$. Black crystals of $\left[(\mathrm{dpqx})_{2} \operatorname{Ir}(\mathrm{fppz})\right](\mathbf{1})$ were obtained from repeated recrystallization using a mixture of $\mathrm{CH}_{2} \mathrm{Cl}_{2}$ and methanol at room temperature (180 mg, $0.19 \mathrm{mmol}, 43 \%$ ). Solubility in $\mathrm{CH}_{2} \mathrm{Cl}_{2}$ at $28^{\circ} \mathrm{C}: 26 \mathrm{mg} / \mathrm{mL}$.

Spectral data for 1: MS (FAB, $\left.{ }^{193} \mathrm{Ir}\right) \mathrm{m} / \mathrm{z}, 967\left(\mathrm{M}^{+}\right) ;{ }^{1} \mathrm{H}$ NMR $\left(500 \mathrm{MHz}, \mathrm{CDCl}_{3}, 294 \mathrm{~K}\right) \delta 8.69(\mathrm{~s}, 1 \mathrm{H}), 8.62(\mathrm{~s}, 1 \mathrm{H}), 8.52(\mathrm{~s}$, $1 \mathrm{H}), 8.42\left(\mathrm{~d}, J_{\mathrm{HH}}=8.5 \mathrm{~Hz}, 1 \mathrm{H}\right), 8.39\left(\mathrm{~d}, J_{\mathrm{HH}}=9.0 \mathrm{~Hz}, 1 \mathrm{H}\right), 8.32$ $(\mathrm{s}, 1 \mathrm{H}), 7.75\left(\mathrm{~d}, J_{\mathrm{HH}}=8.0 \mathrm{~Hz}, 1 \mathrm{H}\right), 7.71\left(\mathrm{~d}, J_{\mathrm{HH}}=8.5 \mathrm{~Hz}, 1 \mathrm{H}\right)$, 7.69-7.40 (m, 2H); $\left.{ }^{13} \mathrm{C} \mathrm{NMR} \mathrm{(125} \mathrm{MHz,} \mathrm{CDCl}_{3}, 294 \mathrm{~K}\right) \delta 165.3$, 163.8, 160.1, 155.2, 154.4, 153.0, 152.8, 149.7, 147.0, 146.4, 145.4, $144.4\left(\mathrm{q}, J_{\mathrm{CF}}=35 \mathrm{~Hz}\right), 141.6,140.4,140.2,140.0,139.9,139.7$, $138.3,136.9,134.5,131.2,130.8,130.3,130.0,129.9$ (2C), 129.8 (2C), 129.7, 129.3, 129.2 (br, 2C), 129.1, 129.0 (2C), 128.8 (br, 2C), 128.7, 128.6, 127.2, 124.6, $122.5\left(\mathrm{q}, J_{\mathrm{CF}}=266 \mathrm{~Hz}\right), 122.1$,

(8) Darke, J. M.; Lesiecki, M. L.; Camaioni, D. M. Chem. Phys. Lett. $1985,113,530$

(9) Nonoyama, M. J. Organomet. Chem. 1975, 86, 263. 
121.4 (2C), 121.1, 119.6, 102.3; ${ }^{19} \mathrm{~F}$ NMR (470 MHz, $\mathrm{CDCl}_{3}, 294$ K) $\delta-60.0(3 \mathrm{~F})$. Anal. Calcd for $\mathrm{C}_{50} \mathrm{H}_{33} \mathrm{Cl}_{2} \mathrm{~F}_{3} \mathrm{IrN}_{7}: \mathrm{N}, 9.32 ; \mathrm{C}$, 57.09; H, 3.16. Found: N, 9.30; C, 57.09 H, 3.55.

Preparation of $\left[(\mathbf{d f q x})_{2} \mathbf{I r C l}\right]_{2}$. On the basis of a procedure similar to that described for $\left[(\mathrm{dpqx})_{2} \mathrm{IrCl}\right]_{2}$, the second chloridebridged complex $\left[(\mathrm{dfqx})_{2} \mathrm{IrCl}\right]_{2}$ was synthesized in a yield of $\sim 85 \%$.

Preparation of $\left[(\mathbf{d f q x})_{2} \operatorname{Ir}(\mathbf{f p p z})\right](\mathbf{2})$. Procedures identical with that of 1 were followed, using $200 \mathrm{mg}$ of $\left[(\mathrm{dfqx})_{2} \mathrm{IrCl}\right]_{2}(0.116$ $\mathrm{mmol}), 61 \mathrm{mg}$ of pyrazole (fppz)H $(0.28 \mathrm{mmol})$, and $120 \mathrm{mg}$ of $\mathrm{Na}_{2} \mathrm{CO}_{3}(1.13 \mathrm{mmol})$ in $20 \mathrm{~mL}$ of 2 -methoxyethanol. Dark red crystals of $\left[(\mathrm{dfqx})_{2} \operatorname{Ir}(\mathrm{fppz})\right](2)$ were obtained from column chromatography using hexane and ethyl acetate $(\mathrm{EA})=3: 1$ and crystallization from a mixture of $\mathrm{CHCl}_{3}$ and hexane at $\mathrm{RT}(122$ $\mathrm{mg}, 0.117 \mathrm{mmol}, 51 \%$ ). Solubility in $\mathrm{CH}_{2} \mathrm{Cl}_{2}$ at $28{ }^{\circ} \mathrm{C}$ : $6.5 \mathrm{mg} /$ $\mathrm{mL}$.

Spectral data for 2: MS (FAB, $\left.{ }^{193} \mathrm{Ir}\right) \mathrm{m} / \mathrm{z}, 1039\left(\mathrm{M}^{+}\right) ;{ }^{1} \mathrm{H}$ NMR $\left(400 \mathrm{MHz}, \mathrm{CDCl}_{3}, 294 \mathrm{~K}\right) \delta 8.44\left(\mathrm{~d}, J_{\mathrm{HH}}=5.2 \mathrm{~Hz}, 1 \mathrm{H}\right), 8.00(\mathrm{~d}$, $\left.J_{\mathrm{HH}}=5.2 \mathrm{~Hz}, 1 \mathrm{H}\right), 7.95\left(\mathrm{dd}, J_{\mathrm{HH}}=6.8,1.2 \mathrm{~Hz}, 1 \mathrm{H}\right), 7.91\left(\mathrm{dd}, J_{\mathrm{HH}}\right.$ $=6.8,1.2 \mathrm{~Hz}, 1 \mathrm{H}), 7.83(\mathrm{br}, 2 \mathrm{H}), 7.63-7.60(\mathrm{~m}, 1 \mathrm{H}), 7.52(\mathrm{ddd}$, $\left.J_{\mathrm{HH}}=6.8,5.2,1.2 \mathrm{~Hz}, 1 \mathrm{H}\right), 7.48-7.44(\mathrm{~m}, 1 \mathrm{H}) .7 .42\left(\mathrm{~d}, J_{\mathrm{HH}}=\right.$ $7.2 \mathrm{~Hz}, 1 \mathrm{H}), 7.34-7.23$ (m, 9H), 7.18-7.15 (m, 2H), 7.07-7.04 $(\mathrm{m}, 1 \mathrm{H}), 6.53(\mathrm{~s}, 1 \mathrm{H}), 6.50\left(\mathrm{ddd}, J_{\mathrm{HH}}=9.2,8.8,2.4 \mathrm{~Hz}, 1 \mathrm{H}\right), 6.44$ $\left(\mathrm{ddd}, J_{\mathrm{HH}}=9.2,8.8,2.4 \mathrm{~Hz}, 1 \mathrm{H}\right), 6.37\left(\mathrm{dd}, J_{\mathrm{HH}}=9.2,2.4 \mathrm{~Hz}\right.$, $1 \mathrm{H}), 5.92\left(\mathrm{dd}, J_{\mathrm{HH}}=8.8,2.4 \mathrm{~Hz}, 1 \mathrm{H}\right) ;{ }^{13} \mathrm{C} \mathrm{NMR}\left(125 \mathrm{MHz}, \mathrm{CDCl}_{3}\right.$, $294 \mathrm{~K}) \delta 164.2,164.1\left(\mathrm{~d}, J_{\mathrm{CF}}=234 \mathrm{~Hz}\right), 163.8\left(\mathrm{~d}, J_{\mathrm{CF}}=234 \mathrm{~Hz}\right)$, $163.1,163.0\left(\mathrm{~d}, J_{\mathrm{CF}}=234 \mathrm{~Hz}\right), 162.7,162.0\left(\mathrm{~d}, J_{\mathrm{CF}}=234 \mathrm{~Hz}\right)$, $155.2,155.0,153.0,151.7,150.0,146.9,144.6\left(\mathrm{q}, J_{\mathrm{CF}}=36 \mathrm{~Hz}\right)$, $142.5,141.4$ (2C), 140.1 (2C), 139.8, 138.6, 135.8, 135.5, 132.9 $\left(\mathrm{d}, J_{\mathrm{CF}}=10 \mathrm{~Hz}\right), 132.2\left(\mathrm{~d}, J_{\mathrm{CF}}=10 \mathrm{~Hz}\right), 131.6,131.0(\mathrm{br}, 2 \mathrm{C})$, $130.2,129.8,129.7,129.0,128.8,126.6,124.0,122.6\left(\mathrm{~d}, J_{\mathrm{CF}}=17\right.$ $\mathrm{Hz}), 122.3\left(\mathrm{q}, J_{\mathrm{CF}}=267 \mathrm{~Hz}\right), 122.2,120.3(\mathrm{~d}, J=17 \mathrm{~Hz}), 119.9$, $116.5\left(\mathrm{~d}, 2 \mathrm{C}, J_{\mathrm{CF}}=22 \mathrm{~Hz}\right), 116.0\left(\mathrm{~d}, 2 \mathrm{C} J_{\mathrm{CF}}=22 \mathrm{~Hz}\right), 109.7(\mathrm{~d}$, $\left.2 \mathrm{C} J_{\mathrm{CF}}=22 \mathrm{~Hz}\right), 109.4\left(\mathrm{~d}, 2 \mathrm{C} J_{\mathrm{CF}}=22 \mathrm{~Hz}\right), 102.5 ;{ }^{19} \mathrm{~F}$ NMR $\left(470 \mathrm{MHz}, \mathrm{CDCl}_{3}, 294 \mathrm{~K}\right) \delta-60.0(3 \mathrm{~F}),-108.0,-109.1,-110.2$, -110.8. Anal. Calcd for $\mathrm{C}_{49} \mathrm{H}_{27} \mathrm{~F}_{7} \mathrm{IrN}_{7}$ : C, 56.64; H, 2.62; N, 9.44; Found: C, 56.82; H, 2.79. N, 8.99.

Preparation of $\left[(\mathbf{d f q x})_{2} \operatorname{Ir}(\mathbf{f p t z})\right](3)$. Procedures identical with that of 1 were followed, using $330 \mathrm{mg}$ of $\left[(\mathrm{dfqx})_{2} \mathrm{IrCl}\right]_{2}(0.19 \mathrm{mmol})$, $102 \mathrm{mg}$ of triazole (fptz)H $(0.48 \mathrm{mmol})$, and $200 \mathrm{mg}$ of $\mathrm{Na}_{2} \mathrm{CO}_{3}$ (1.9 mmol) in $30 \mathrm{~mL}$ of 2-methoxyethanol. Orange red crystals of $\left[(\mathrm{dfqx})_{2} \operatorname{Ir}(\mathrm{fptz})\right](3)$ were obtained from column chromatography using hexane and EA $=2: 1$ and crystallization from a mixture of $\mathrm{CHCl}_{3}$ and methanol at RT (191 mg, $\left.0.183 \mathrm{mmol}, 48 \%\right)$. Solubility in $\mathrm{CH}_{2} \mathrm{Cl}_{2}$ at $28{ }^{\circ} \mathrm{C}: 22 \mathrm{mg} / \mathrm{mL}$.

Spectral data for 3: MS (FAB, $\left.{ }^{193} \mathrm{Ir}\right) \mathrm{m} / \mathrm{z} 1040\left(\mathrm{M}^{+}\right) ;{ }^{1} \mathrm{H}$ NMR $\left(500 \mathrm{MHz}, \mathrm{CDCl}_{3}, 294 \mathrm{~K}\right) \delta 8.54\left(\mathrm{~d}, J_{\mathrm{HH}}=5.0 \mathrm{~Hz}, 1 \mathrm{H}\right), 8.26(\mathrm{br}$, $2 \mathrm{H}) 7.97\left(\mathrm{~d}, J_{\mathrm{HH}}=8.0 \mathrm{~Hz}, 1 \mathrm{H}\right), 7.92\left(\mathrm{~d}, J_{\mathrm{HH}}=8.0,1 \mathrm{H}\right), 7.90-$ $7.87(\mathrm{~m}, 2 \mathrm{H}), 7.83(\mathrm{br}, 2 \mathrm{H}), 7.79-7.75(\mathrm{~m}, 1 \mathrm{H}), 7.55\left(\mathrm{t}, J_{\mathrm{HH}}=7.8\right.$ $\mathrm{Hz}, 1 \mathrm{H}), 7.49-7.45(\mathrm{~m}, 2 \mathrm{H}), 7.35-7.28(\mathrm{~m}, 6 \mathrm{H}), 7.20-7.15(\mathrm{~m}$, $2 \mathrm{H}), 7.05\left(\mathrm{t}, J_{\mathrm{HH}}=7.8, \mathrm{~Hz}, 1 \mathrm{H}\right), 6.54\left(\mathrm{ddd}, J_{\mathrm{HH}}=9,8.5,2.5 \mathrm{~Hz}\right.$, $1 \mathrm{H}), 6.47\left(\mathrm{td}, J_{\mathrm{HH}}=9,2.5 \mathrm{~Hz}, 1 \mathrm{H}\right), 6.38\left(\mathrm{dd}, J_{\mathrm{HH}}=9,2.5 \mathrm{~Hz}\right.$, $1 \mathrm{H}), 5.95\left(\mathrm{dd}, J_{\mathrm{HH}}=9.0,2.5 \mathrm{~Hz}, 1 \mathrm{H}\right) ;{ }^{13} \mathrm{C} \mathrm{NMR}\left(125 \mathrm{MHz} \mathrm{CDCl}_{3}\right.$, $294 \mathrm{~K}) \delta 164.1\left(\mathrm{~d}, J_{\mathrm{CF}}=226 \mathrm{~Hz}\right), 163.9\left(\mathrm{~d}, J_{\mathrm{CF}}=226 \mathrm{~Hz}\right), 163.8$, $163.0\left(\mathrm{~d}, J_{\mathrm{CF}}=226 \mathrm{~Hz}\right), 162.9,162.5,162.0\left(\mathrm{~d}, J_{\mathrm{CF}}=226 \mathrm{~Hz}\right)$, $160.8,156.6\left(\mathrm{q}, J_{\mathrm{CF}}=36 \mathrm{~Hz}\right), 152.9(2 \mathrm{C}), 151.8,151.0,147.0$, $142.3,141.2,140.8,140.2,140.1,139.8,139.4,135.5,135.4,133.0$ $\left(\mathrm{d}, J_{\mathrm{CF}}=9 \mathrm{~Hz}\right), 132.3(\mathrm{~d}, J=9 \mathrm{~Hz}), 131.9,131.0(\mathrm{br}, 2 \mathrm{C}), 130.4$, $130.2,130.1,129.3,129.2,126.2,124.8,123.8,122.7\left(\mathrm{~d}, J_{\mathrm{CF}}=17\right.$ $\mathrm{Hz}), 121.9,120.7\left(\mathrm{~d}, J_{\mathrm{CF}}=17 \mathrm{~Hz}\right), 120.1\left(\mathrm{q}, J_{\mathrm{CF}}=268 \mathrm{~Hz}\right), 116.6$ $\left(\mathrm{d}, 2 \mathrm{C}, J_{\mathrm{CF}}=21 \mathrm{~Hz}\right), 116.2\left(\mathrm{~d}, 2 \mathrm{C}, J_{\mathrm{CF}}=21 \mathrm{~Hz}\right), 110.0(\mathrm{~m}, 4 \mathrm{C})$; ${ }^{19} \mathrm{~F}$ NMR (470 MHz, $\left.\mathrm{CDCl}_{3}, 294 \mathrm{~K}\right) \delta-63.7(3 \mathrm{~F}),-107.3,-108.3$, -109.8, -110.4. Anal. Calcd for $\mathrm{C}_{48} \mathrm{H}_{26} \mathrm{~F}_{7} \mathrm{IrN}_{8}$ : C, 55.44; H, 2.52; N, 10.77. Found: C, 54.83; H, 2.66; N, 10.47.
Preparation of $\left[(\mathbf{d f q x})_{2} \operatorname{Ir}(\mathbf{b p p z})\right]$ (4). Procedures identical with that of 1 were followed, using $300 \mathrm{mg}$ of $\left[(\mathrm{dfqx})_{2} \mathrm{IrCl}\right]_{2}(0.174$ $\mathrm{mmol}), 87 \mathrm{mg}$ of pyrazole (bppz)H $(0.43 \mathrm{mmol})$, and $180 \mathrm{mg}$ of $\mathrm{Na}_{2} \mathrm{CO}_{3}(1.7 \mathrm{mmol})$ in $30 \mathrm{~mL}$ of 2-methoxyethanol. Dark red crystals of $\left[(\mathrm{dfqx})_{2} \operatorname{Ir}(\mathrm{bppz})\right]$ (4) were obtained from column chromatography using hexane and $\mathrm{EA}=2: 1$ and crystallization from a mixture of $\mathrm{CHCl}_{3}$ and methanol at RT (124 mg, $0.12 \mathrm{mmol}$, $35 \%)$. Solubility in $\mathrm{CH}_{2} \mathrm{Cl}_{2}$ at $28{ }^{\circ} \mathrm{C}: 18 \mathrm{mg} / \mathrm{mL}$.

Spectral data for 4: MS (FAB, $\left.{ }^{193} \mathrm{Ir}\right) \mathrm{m} / \mathrm{z} 1027\left(\mathrm{M}^{+}\right) ;{ }^{1} \mathrm{H}$ NMR $\left(400 \mathrm{MHz}, \mathrm{CDCl}_{3}, 294 \mathrm{~K}\right) \delta 8.32\left(\mathrm{~d}, J_{\mathrm{HH}}=5.2 \mathrm{~Hz}, 1 \mathrm{H}\right), 8.07(\mathrm{~d}$, $\left.J_{\mathrm{HH}}=9.0 \mathrm{~Hz}, 1 \mathrm{H}\right), 7.96\left(\mathrm{~d}, J_{\mathrm{HH}}=7.4 \mathrm{~Hz}, 1 \mathrm{H}\right), 7.88\left(\mathrm{~d}, J_{\mathrm{HH}}=7.4\right.$ $\mathrm{Hz}, 1 \mathrm{H}), 7.83$ (br, 2H), $7.54\left(\mathrm{~d}, J_{\mathrm{HH}}=9.0 \mathrm{~Hz}, 1 \mathrm{H}\right), 7.53-7.44(\mathrm{~m}$, $3 \mathrm{H}), 7.33-7.19(\mathrm{~m}, 7 \mathrm{H}), 7.15-7.05(\mathrm{~m}, 5 \mathrm{H}), 6.47\left(\mathrm{td}, J_{\mathrm{HH}}=9.0\right.$, $2.6 \mathrm{~Hz}, 1 \mathrm{H}), 6.40\left(\mathrm{ddd}, J_{\mathrm{HH}}=9.0,8.4,2.6 \mathrm{~Hz}, 1 \mathrm{H}\right), 6.31\left(\mathrm{dd}, J_{\mathrm{HH}}\right.$ $=9.0,2.6 \mathrm{~Hz}, 1 \mathrm{H}), 6.14(\mathrm{~s}, 1 \mathrm{H}), 5.87\left(\mathrm{dd}, J_{\mathrm{HH}}=9.0,2.6 \mathrm{~Hz}, 1 \mathrm{H}\right)$, $1.27(\mathrm{~s}, 9 \mathrm{H}) ;{ }^{13} \mathrm{C} \mathrm{NMR}\left(125 \mathrm{MHz}, \mathrm{CDCl}_{3}, 294 \mathrm{~K}\right) \delta 165.2,164.5$, $164.1\left(\mathrm{~d}, J_{\mathrm{CF}}=243 \mathrm{~Hz}\right), 163.8\left(\mathrm{~d}, J_{\mathrm{CF}}=243 \mathrm{~Hz}\right), 162.9\left(\mathrm{~d}, J_{\mathrm{CF}}=\right.$ $243 \mathrm{~Hz}), 162.8,162.1\left(\mathrm{~d}, J_{\mathrm{CF}}=243 \mathrm{~Hz}\right), 156.5$ (br, 2C), 152.6, 151.5, 148.7, 146.5, 142.4, 141.7, 141.6, 140.7, 140.1, 140.0, 138.0, $135.9,135.6,132.7\left(\mathrm{~d}, J_{\mathrm{CF}}=9 \mathrm{~Hz}\right), 132.0\left(\mathrm{~d}, J_{\mathrm{CF}}=9 \mathrm{~Hz}\right), 131.2$, 131.1, 130.0, 129.7 (2C), 129.6, 128.9 (2C), 128.5 (2C), 127.2, $124.5,122.2\left(\mathrm{~d}, J_{\mathrm{CF}}=17 \mathrm{~Hz}\right), 120.7,120.1\left(\mathrm{~d}, J_{\mathrm{CF}}=17 \mathrm{~Hz}\right), 119.2$, $116.1(\mathrm{br}, 4 \mathrm{C}), 109.4$ (d, 2C, $\left.J_{\mathrm{CF}}=22 \mathrm{~Hz}\right), 108.7$ (d, 2C, $J_{\mathrm{CF}}=22$ $\mathrm{Hz}), 32.3,31.4$ (3C); ${ }^{19} \mathrm{~F}$ NMR (470 $\left.\mathrm{MHz}, \mathrm{CDCl}_{3}, 294 \mathrm{~K}\right) \delta$ $-108.6,-109.7,-110.4,-110.8$. Anal. Calcd for $\mathrm{C}_{52} \mathrm{H}_{36} \mathrm{~F}_{4} \mathrm{IrN}_{7}$ : C, 60.81; H, 3.53; N, 9.55. Found: C, 60.39; H, 3.93; N, 9.47.

X-ray Structural Analysis. Single-crystal X-ray diffraction data were measured on a Bruker Smart ApexCCD diffractometer using $\lambda(\mathrm{Mo} K \alpha)$ radiation $(\lambda=0.71073 \AA)$. The data collection was executed using the SMART program. Cell refinement and data reduction were made with the SAINT program. The structure was determined using the SHELXTL/PC program and refined using fullmatrix least squares. All non-hydrogen atoms were refined anisotropically, whereas hydrogen atoms were placed at the calculated positions and included in the final stage of refinements with fixed parameters.

Selected crystal data for $\mathbf{1}: \mathrm{C}_{49} \mathrm{H}_{31} \mathrm{~F}_{3} \mathrm{~N}_{7} \mathrm{Ir}_{\mathrm{r}} \cdot \mathrm{CH}_{2} \mathrm{Cl}_{2}, M=1051.93$; triclinic, space group $P \overline{1} ; a=11.1500(5), b=12.5173(5), c=$ 17.0626(7) $\AA$; $\alpha=100.4154(8), \beta=92.6985(9), \gamma=114.9504(8)^{\circ}$; $V=2103.2(2) \AA^{3}, Z=2 ; \rho_{\text {calcd }}=1.661 \mathrm{~g} \mathrm{~cm}^{-3} ; F(000)=1040$; crystal size $=0.35 \times 0.35 \times 0.12 \mathrm{~mm}^{3} ; \lambda($ Mo K $\alpha)=0.7107 \AA$; $T=295(2) \mathrm{K} ; \mu=3.361 \mathrm{~mm}^{-1} ; 9651$ reflections collected $\left(\mathrm{R}_{\mathrm{int}}=\right.$ $0.0365)$, maximum and minimum transmission $=0.6885$ and 0.3859; GOF on $F^{2}=1.049$; final $\mathrm{R}_{1}[I>2 \sigma(I)]=0.0304$ and $\mathrm{wR}_{2}[I>2 \sigma(I)]=0.0724$; final $\mathrm{R}_{1}$ (all data) $=0.0352$ and $\mathrm{wR}_{2}$ (all data $=0.0767$; largest difference peak and hole $=1.375$ and $-0.955 \mathrm{e} / \AA^{3}$.

Device Fabrication. The light-emitting devices with the configuration of ITO/poly(styrenesulfonate)-doped poly(3,4-ethylenedioxythiophene) (PEDOT:PSS) (35 nm)/doped emitting layer (50$60 \mathrm{~nm}) / \mathrm{TPBI}(30 \mathrm{~nm}) / \mathrm{Mg}: \mathrm{Ag}(100 \mathrm{~nm}) / \mathrm{Ag}(100 \mathrm{~nm})$ were fabricated. The PEDOT:PSS was spin coated onto the ITO glass and dried at $80{ }^{\circ} \mathrm{C}$ for $12 \mathrm{~h}$ under vacuum to improve the smoothness. Films of poly(vinylcarbazole) (PVK), consisting of 2-(4-biphenylyl)-5-(4tert-butylphenyl)-1,3,4-oxadiazole (PBD) (30 wt \%) and different amounts of complex $1(0.18,1.8$, and $5.3 \mathrm{wt} \%$, respectively) were spin coated on top of the PEDOT:PSS layer using chlorobenzene as the solvent, followed by drying at $60{ }^{\circ} \mathrm{C}$ for $3 \mathrm{~h}$ under vacuum. Prior to film casting, the polymer solution was filtered through a Teflon filter $(0.45 \mu \mathrm{m})$ to remove the larger particulates. The $2,2^{\prime}, 2^{\prime \prime}-$ (1,3,5-benzenetriyl)tris[1-phenyl-1H-benimidazole] (TPBI) layer was grown by thermal sublimation in a vacuum of $3 \times 10^{-6}$ Torr to use as the electron-transport layer, which would block holes and 


\section{Scheme 1}

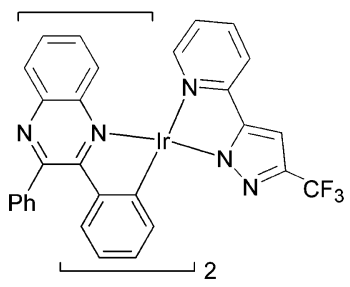

(1)

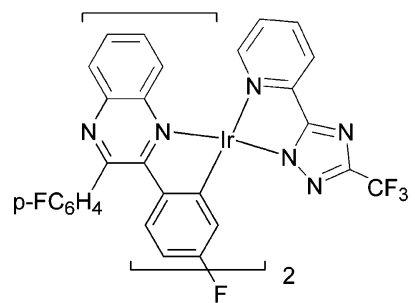

(3)

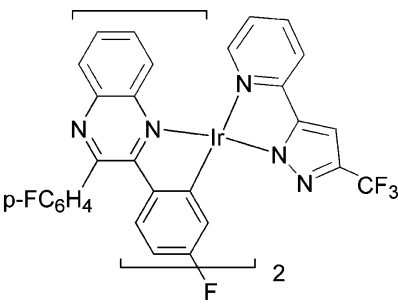

(2)

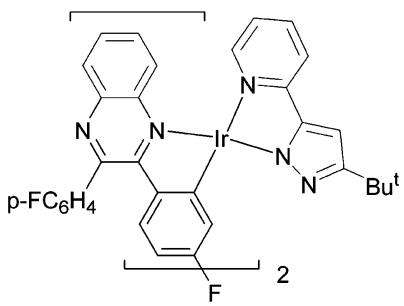

(4) excitons. ${ }^{10}$ The cathode Mg:Ag alloy $(10: 1,100 \mathrm{~nm})$ was deposited onto the TPBI layer by coevaporation. An additional layer of $\mathrm{Ag}$ $(100 \mathrm{~nm})$ was deposited onto the cathode as a protective coating. The current-voltage-luminance was measured in ambient conditions with a Keithley 2400 source meter and a Newport $1835 \mathrm{C}$ optical meter equipped with $818 \mathrm{ST}$ silicon photodiode.

\section{Results}

Synthesis and Characterization. The reaction of $(\mathrm{dpqx}) \mathrm{H}$ and $\mathrm{IrCl}_{3} \cdot n \mathrm{H}_{2} \mathrm{O}$ in refluxing methoxyethanol afforded chloridebridged complex $\left[(\mathrm{dpqx})_{2} \mathrm{IrCl}\right]_{2}$. The monomeric complex $\left[(\mathrm{dpqx})_{2} \operatorname{Ir}(\mathrm{fppz})\right]$ (1) was obtained by the treatment of $\left[(\mathrm{dpqx})_{2} \mathrm{IrCl}\right]_{2}$ with pyrazole $(\mathrm{fppz}) \mathrm{H}$ in the presence of $\mathrm{Na}_{2} \mathrm{CO}_{3}$, where (fppz)H = 3-(trifluoromethyl)-5-(2-pyridyl)pyrazole. Moreover, a second quinoxaline ligand, (dfqx)H, with two 4-fluorophenyl substituents was also synthesized for the purpose of subtle tuning of the emission wavelength. Thus, condensation of 1,2-phenylenediamine and 4,4'difluorobenzil gave the corresponding 4-fluorophenylsubstituted quinoxaline in a high yield. Subsequently, the reactions were executed using the identical metal reagent $\mathrm{IrCl}_{3} \cdot n \mathrm{H}_{2} \mathrm{O}$, followed by treatment with the pyrazolate or triazolate chelate ligands such as $(\mathrm{fppz}) \mathrm{H},(\mathrm{fptz}) \mathrm{H}$, and (bptz)H to afford three additional complexes, i.e., [(dfqx $)_{2} \mathrm{Ir}-$ (fppz)] (2), [(dfqx $\left.)_{2} \operatorname{Ir}(\mathrm{fptz})\right](3)$, and [(dfqx $\left.)_{2} \operatorname{Ir}(\mathrm{bppz})\right](\mathbf{4})$; their molecular structures are shown in Scheme 1. All iridium complexes 1-4 are highly soluble in chlorinated solvents and show negligible decomposition in solution within a period of $24 \mathrm{~h}$. Detailed characterizations were conducted using MS, NMR, and elemental analysis (see Experimental Section), whereas the parent dpqx complex 1 was further identified using single-crystal X-ray analysis to establish their three-dimensional structures.

As depicted in Figure 1, complex 1 reveals a distorted octahedral geometry around iridium, consisting of two cyclometalated dpqx quinoxaline ligands and one fppz pyrazolate ligand. The quinoxaline ligands adopt a mutual

(10) Vaeth, K. M.; Tang, C. W. J. Appl. Phys. 2002, 92, 3447.

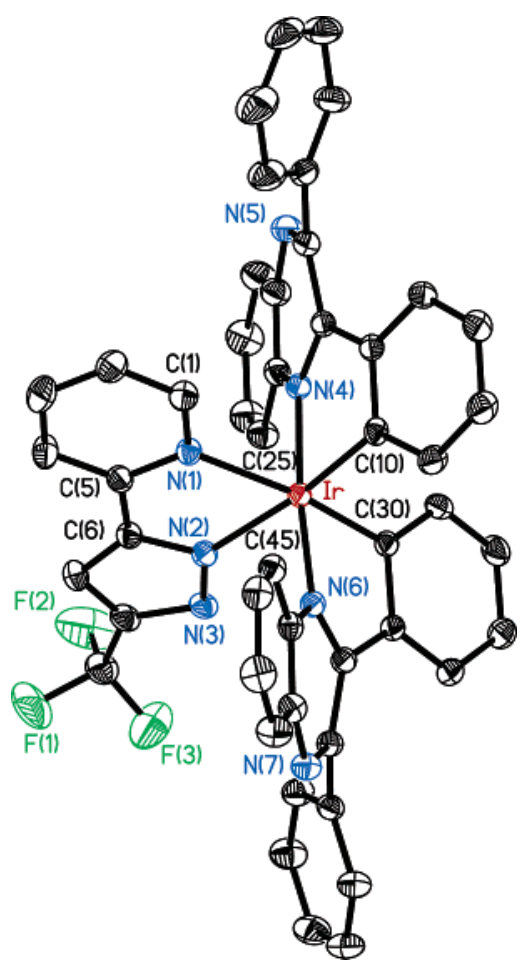

Figure 1. ORTEP diagram of $\mathbf{1}$ with thermal ellipsoids shown at the $30 \%$ probability level. Bond distances $(\AA)$ : $\mathrm{Ir}-\mathrm{C}(10)=1.996(3), \mathrm{Ir}-\mathrm{C}(30)=$ $1.992(3), \operatorname{Ir}-\mathrm{N}(1)=2.211(3), \operatorname{Ir}-\mathrm{N}(2)=2.128(3), \operatorname{Ir}-\mathrm{N}(4)=2.059(3)$, $\operatorname{Ir}-\mathrm{N}(6)=2.064(3) \AA$. Nonbonding distances $(\AA): \mathrm{C}(25) \cdots \mathrm{N}(2)=3.12$, $\mathrm{C}(25) \cdots \mathrm{N}(3)=3.23, \mathrm{C}(25) \cdots \mathrm{C}(6)=3.80, \mathrm{C}(45) \cdots \mathrm{N}(1)=3.28, \mathrm{C}(45) \cdots$ $\cdot \mathrm{C}(1)=3.48, \mathrm{C}(45) \cdots \mathrm{C}(5)=4.05$ A. Bond angles (deg): $\mathrm{C}(10)-\mathrm{Ir}-\mathrm{N}(4)$ $=79.0(1), \mathrm{C}(30)-\mathrm{Ir}-\mathrm{N}(6)=79.3(1), \mathrm{C}(30)-\mathrm{Ir}-\mathrm{C}(10)=93.2(1), \mathrm{N}(2)-$ $\mathrm{Ir}-\mathrm{N}(1)=75.2(1), \mathrm{N}(4)-\mathrm{Ir}-\mathrm{N}(6)=174.3(2)$.

eclipse configuration with their coordinated nitrogen atoms $\mathrm{N}(4)$ and $\mathrm{N}(6)$ and carbon atoms $\mathrm{C}(10)$ and $\mathrm{C}(30)$ being in a trans and a cis orientation, respectively, while the fppz pyrazolate is located at a unique position opposite to the carbon atoms of the dpqx ligands. This ligand arrangement is akin to those of the parent phenylpyridine ligands in chloride-bridged dimer complex $\left[(\operatorname{ppy})_{2} \operatorname{Ir}(\mu-\mathrm{Cl})\right]_{2},{ }^{11}$ diketonate complexes such as (ppy $)_{2} \operatorname{Ir}(\mathrm{acac}){ }^{12}$ and even the associated derivatives with pyrazolyl ancillary ligands, ${ }^{13}$ suggesting that the pyrazolate ligand in our case is attached to the metal via a simple replacement of both chloride ligands. In addition, both quinoxaline ring skeletons exhibited large distortion with respect to the cyclometalated phenyl fragment. This abnormal phenomenon is evidenced by the large deformation angles of 35.3 and $36^{\circ}$ calculated by using the least-squares planes of the cyclometalated phenyl group and the outer $\mathrm{C}_{6}$ hexagon of the adjacent quinoxaline fragment. It appears to us that the nonbonding repulsion between $C(25)$ and $C(45)$ atoms of the dpqx ligands and the perpendicularly arranged fppz pyrazolate ligands is the main driving force to induce the large distortion. This viewpoint is supported by the interligand nonbonding contacts of ca. 3.5 $\AA$ between $\mathrm{C}-\mathrm{C}$ and $\mathrm{C}-\mathrm{N}$, the distance of which is

(11) Graces, F. O.; King, K. A.; Watts, R. J. Inorg. Chem. 1988, 27, 3464.

(12) Lamansky, S.; Djurovich, P.; Murphy, D.; Abdel-Razzaq, F.; Lee, H.E.; Adachi, C.; Burrows, P. E.; Forrest, S. R.; Thompson, M. E. J. Am. Chem. Soc. 2001, 123, 4304.

(13) Li, J.; Djurovich, P. I.; Alleyne, B. D.; Tsyba, I.; Ho, N. N.; Bau, R.; Thompson, M. E. Polyhedron 2004, 23, 419. 
Hwang et al.

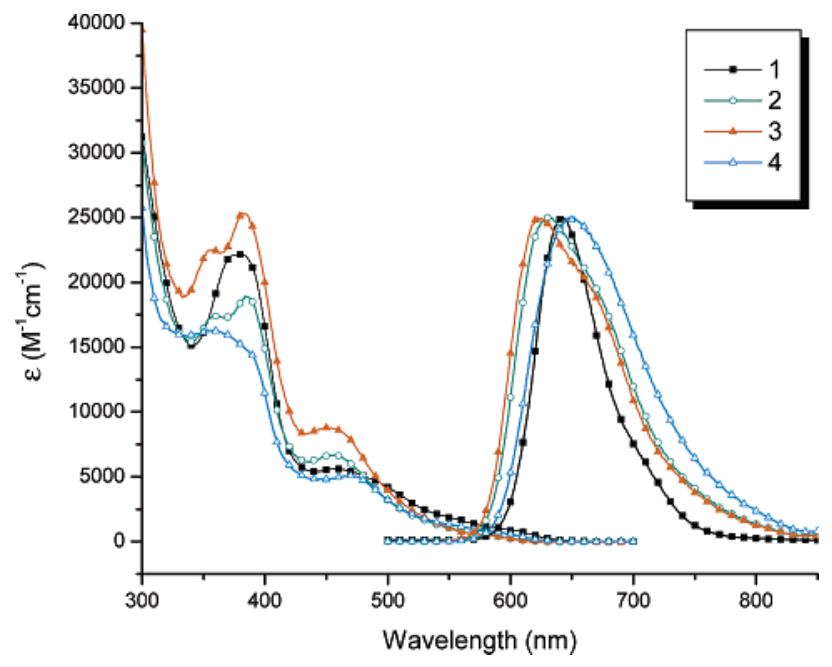

Figure 2. UV-vis absorption and normalized emission spectra of complexes $\mathbf{1}(\square), \mathbf{2}(\mathrm{O}), \mathbf{3}(\mathbf{\Delta})$, and $\mathbf{4}(\triangle)$ in $\mathrm{CH}_{2} \mathrm{Cl}_{2}$ at room temperature.

Table 1. Photophysical Properties of Iridium Complexes 1-4 at Room Temperature

\begin{tabular}{llccc}
\hline \multicolumn{1}{c}{$\lambda_{\text {abs }}{ }^{\max }\left(\epsilon, \mathrm{M}^{-1} \mathrm{~cm}^{-1}\right)$} & $\begin{array}{c}\lambda_{\mathrm{em}}{ }^{\max } \\
(\mathrm{nm})\end{array}$ & $\Phi_{\text {degassed }}$ & $\begin{array}{c}\tau_{\text {degassed }} \\
(\mu \mathrm{s})\end{array}$ \\
\hline 1 & $381(23000), 458(6100)$ & 642 & 0.40 & 1.9 \\
2 & $359(17500), 384(19000), 453(6700)$ & 630 & 0.83 & 2.8 \\
3 & $357(22500), 382(25400), 450(8800)$ & 622 & 0.85 & 3.3 \\
4 & $359(16300), 469(5100)$ & 649 & 0.62 & 1.9
\end{tabular}

consistent with the interplanar separation between aromatic fragments showing substantial $\pi-\pi$ stacking interaction. ${ }^{14}$

Photophysical Data. The absorption and luminescence spectra of complexes $\mathbf{1 - 4}$ in $\mathrm{CH}_{2} \mathrm{Cl}_{2}$ are depicted in Figure 2. The strong absorption bands in the UV region with distinct vibronic features are assigned to the spin-allowed ${ }^{1} \pi \pi^{*}$ transition of the cyclometalated quinoxaline ligands. The next lower energy absorption with peak wavelengths in the region of 440-475 $\mathrm{nm}$ can be ascribed to a typical spin-allowed metal to ligand charge-transfer ( $\left.{ }^{1} \mathrm{MLCT}\right)$ transition, while their extinction coefficients at peak wavelengths are in the range $5100-8800 \mathrm{M}^{-1} \mathrm{~cm}^{-1}$ and tend to decrease in the order of $\mathbf{3}>\mathbf{2}>\mathbf{1}>\mathbf{4}$. Finally, the weak shoulder extending into the visible region are believed to be associated with both spin-orbit coupling enhanced ${ }^{3} \pi \pi^{*}$ and ${ }^{3}$ MLCT transitions.

Highly intensive luminescence was observed for $\mathbf{1 - 4}$ in degassed $\mathrm{CH}_{2} \mathrm{Cl}_{2}$ with $\lambda_{\max }$ located at $642 \mathrm{~nm}, 630,622$, and $649 \mathrm{~nm}$, respectively. The entire emission band originating from a triplet state manifold was ascertained by the $\mathrm{O}_{2}$ quenching rate constant of as high as $(1.5-2.0) \times 10^{9} \mathrm{M}^{-1}$ $\mathrm{s}^{-1}$ for all samples. The significant overlap of the $0-0$ onsets between emission signal and the lowest energy absorption band, in combination with a broad, structureless spectral feature, leads us to conclude that the phosphorescence originates primarily from the ${ }^{3} \mathrm{MLCT}$ state, together perhaps with a lesser contribution from the ${ }^{3} \pi \pi$ excited states. In comparison to $\mathbf{1}$ with the cyclometalated phenyl group, complex 2 bearing the 4 -fluorophenyl group reveals an $\sim 12$

(14) (a) Chan, S.-C.; Chan, M. C. W.; Wang, Y.; Che, C.-M.; Cheung, K.-K.; Zhu, N. Chem.-Eur. J. 2001, 7, 4180. (b) Kato, M.; Takahashi, J.; Sugimoto, Y.; Kosuge, C.; Kishi, S.; Yano, S. J. Chem. Soc., Dalton Trans. 2001, 747.

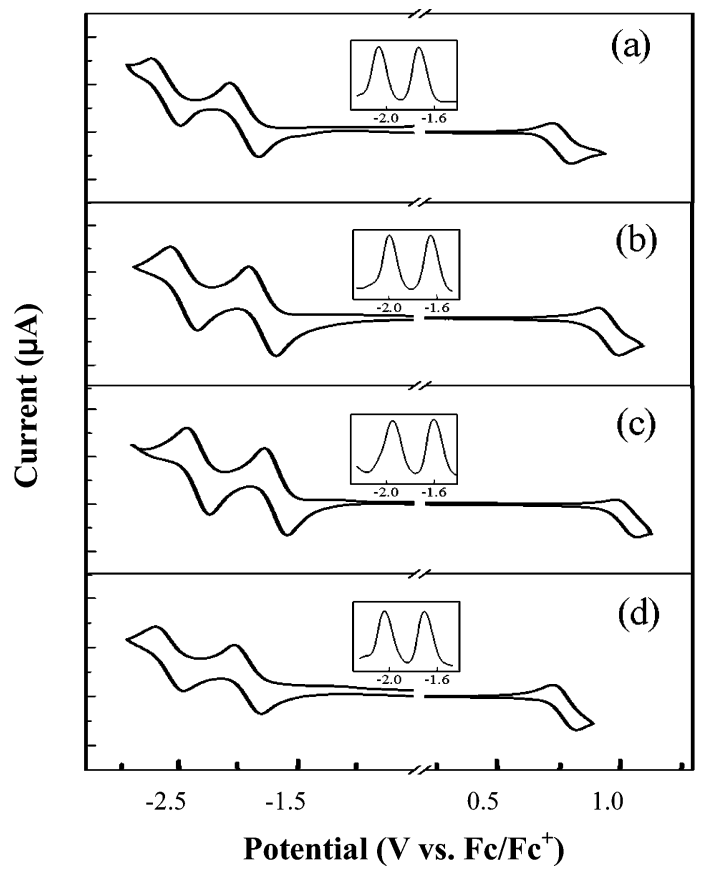

Figure 3. Cyclic voltammograms of (a) 1, (b) 2, (c) 3, and (d) 4. Inset: Differential pulse voltammetry in the reduction region.

Table 2. Electrochemical Properties of Complexes 1-4

\begin{tabular}{ccc} 
& $E_{1 / 2^{\mathrm{ox}}}(\mathrm{V})^{a}$ & $E_{1 / 2}{ }^{\mathrm{red}}(\mathrm{V})^{a}$ \\
\hline 1 & 0.76 & $-1.73,-2.06$ \\
2 & 0.96 & $-1.65,-2.00$ \\
3 & 1.03 & $-1.61,-1.95$ \\
4 & 0.77 & $-1.71,-2.04$
\end{tabular}

${ }^{a}$ Potential values referenced vs $\mathrm{Fc} / \mathrm{Fc}^{+}$.

$\mathrm{nm}$ hypsochromic shift in the emission peak wavelength and can qualitatively be rationalized by a decrease of $\pi^{*} \mathrm{MO}$ energy level due to the stronger electron-withdrawing character of the fluorine atom at a para position. Moreover, with respect to $\mathbf{2}$, altering the third chelate ligand from fppz to fptz (3) and bppz (4) results in an $8 \mathrm{~nm}$ blue shift and a $19 \mathrm{~nm}$ red shift in emission peak maxima $\lambda_{\max }$, respectively. This observation is in accordance with the $\pi$-accepting nature of the triazolate ligand in $\mathbf{3}$ as well as the expected electrondonating property of the tert-butyl group in $\mathbf{4}$, which affects the energy level of $\pi \pi^{*}$ excited states (vide infra). Table 1 lists the corresponding photophysical data for the studied complexes in solution phase at room temperature. The observed lifetimes of ca. 1.9-3.3 $\mu$ s, together with high quantum yields of $0.4-0.8$, in degassed $\mathrm{CH}_{2} \mathrm{Cl}_{2}$ for all studied complexes lead us to deduce the radiative lifetimes of 3.0-4.8 $\mu$ s, which are considerably shorter than those of most reported red-emitting $\operatorname{Ir}(\mathrm{III})$ complexes.

Electrochemistry. The electrochemical behavior of these Ir metal complexes was investigated by cyclic voltammetry using ferrocene as the internal standard. The results are displayed in Figure 3, with the respective redox data listed in Table 2. During the anodic scan in $\mathrm{CH}_{2} \mathrm{Cl}_{2}$, all iridium metal complexes exhibited a reversible oxidation with potentials in the region $0.76-1.03 \mathrm{~V}$. Upon the switch to the cathodic sweep in THF, two reversible reduction processes, with potentials ranging from -1.61 to $-2.06 \mathrm{~V}$, 
were detected for all of them. Additional data provided by differential pulse voltammetry (DPV) also showed two distinct reduction processes. As revealed previously by electrochemical studies and theoretical calculations, ${ }^{15,16}$ the oxidation occurred mainly at the Ir metal cationic site, together with a minor contribution from the cyclometalated phenyl fragment, whereas the double reversible reductions occur primarily on the stronger electron-accepting heterocyclic portion of the cyclometalated $\mathrm{C} \wedge \mathrm{N}$ ligands. Accordingly, replacing the phenyl fragment with a 4-fluorophenyl moiety would significantly affect the electrochemical properties of these metal complexes. This was first demonstrated by the greater oxidation potential of $2(0.96 \mathrm{~V})$ vs that of parent complex $1(0.76 \mathrm{~V})$. At the same time, the reduction potentials of $\mathbf{2}$ are also shifted from those of the complex $\mathbf{1}$ $(-1.73$ and $-2.06 \mathrm{~V})$ to a less negative value of -1.65 and $-2.00 \mathrm{~V}$, respectively. Our data are also in good agreement with those of the related Ir cyclometalated complexes documented in literature, ${ }^{17}$ concluding that the addition of the fluorine substituent on the phenyl rings of cyclometalated ligands would notably increase the oxidation potential and concurrently decrease the reduction potential.

Similarly, the redox potentials of these Ir complexes are also affected by the ancillary LX ligand. This was revealed by the fact that substitution of the fppz ligand by the more electron-donating bppz ligand markedly decreased the oxidative potential from $0.96 \mathrm{~V}$ of 2 to $0.77 \mathrm{~V}$ of $\mathbf{4}$, while replacement of the fppz ligand with a more electron-deficient fptz led to an anodical shift from $0.96 \mathrm{~V}$ for 2 to $1.03 \mathrm{~V}$ observed in $\mathbf{3}$. It should be noted that minor changes at the reduction potential were also observed and were mainly associated with the cyclometalated ligands, to which the ancillary LX ligand can still transmit its electronic nature via an inductive effect passing through the central metal atom. The reduction potentials shown in Table 2 are fully consistent with this delineation; however, the variation of the data is far less significant than that imposed on the respective oxidative potential.

Electroluminescent Devices. To demonstrate the basic electrophosphorescent properties, we selected complex $\mathbf{1}$, which exhibits a saturated red emission, for the fabrication of PLED and testing of their performances. The devices consist of a multilayer configuration ITO/PEDOT:PSS/ PVK-PBD (30 wt \%): $x$ wt $\%$ of 1/TPBI/Mg:Ag/Ag (100 nm), where ITO, PEDOT:PSS, PVK, PBD, TPBI, and $\mathrm{Mg}: \mathrm{Ag}$ denote indium tin oxide, poly(styrenesulfonate)doped poly(3,4-ethylenedioxythiophene), poly(vinylcarbazole), 2-(4-biphenylyl)-5-(4-tert-butylphenyl)-1,3,4-oxadiazole, 2,2',2"-(benzene-1,3,5-triyl)tris[1-phenyl-1 $H$-benzimidazole], and magnesium:silver alloy (ca. 10:1), respectively. A thin film of PEDOT was spin-cast onto a precleaned ITO surface and then baked at $80{ }^{\circ} \mathrm{C}$ for $12 \mathrm{~h}$ under vacuum to

(15) (a) Ohsawa, Y.; Sprouse, S.; King, K. A.; DeArmond, M. K.; Hanck, K. W.; Watts, R. J. J. Phys. Chem. 1987, 91, 1047. (b) Tamayo, A. B.; Alleyne, B. D.; Djurovich, P. I.; Lamansky, S.; Tsyba, I.; Ho, N. N.; Bau, R.; Thompson, M. E. J. Am. Chem. Soc. 2003, 125, 7377. (16) Hay, P. J. J. Phys. Chem. A. 2002, 106, 1634.

(17) Brooks, J.; Babayan, Y.; Lamansky, S.; Djurovich, P. I.; Tsyba, I.; Bau, R.; Thompson, M. E. Inorg. Chem. 2002, 41, 3055.

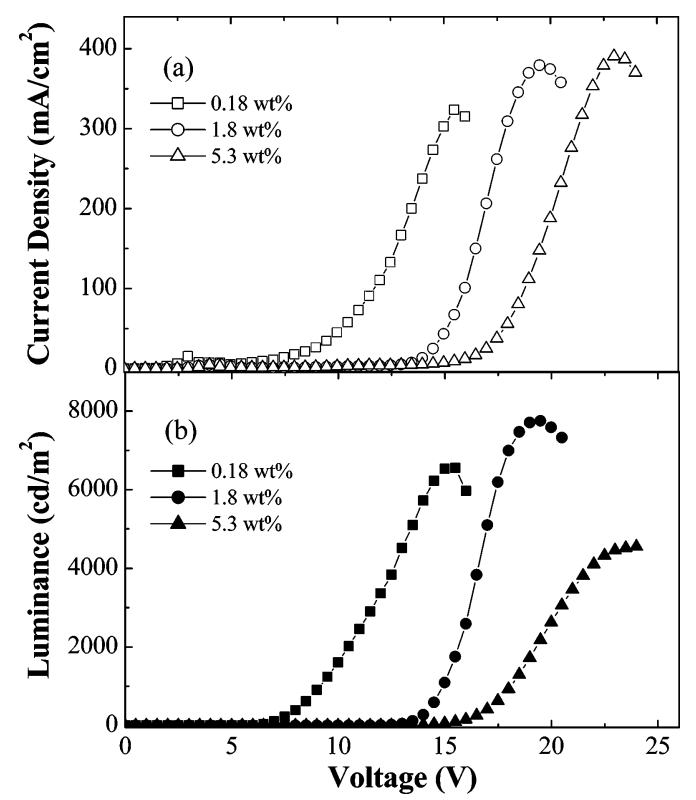

Figure 4. (a) Current density versus applied voltage for the doped devices showing dopant concentrations of $\mathbf{1}$ at $0.18,1.8$, and 5.3 wt \% level. (b) Plots of luminance versus applied voltage.

improve hole injection and to increase substrate smoothness. The emitting layer, PVK-PBD (30 wt \%) with different doping concentrations of complex $1(0.18,1.8$, and $5.3 \mathrm{wt} \%$, respectively; corresponding to complex $\mathbf{1} / \mathrm{PVK}$ monomer unit molar ratios of $0.05: 100,0.50: 100$, and 1.5:100), was then spin-cast onto the surface of PEDOT. A typical film thickness of the emitting layer was 50-60 $\mathrm{nm}$. Through the blend with PBD, the electron transport in the emitting layer was facilitated. A layer of TPBI electron-injection/transport layer was also used at the cathode for the hole-blocking as well as the exciton confinement.

Figure $4 \mathrm{a}$ shows the current-voltage curves of the electroluminescent devices for $\mathbf{1}$ at various doping concentrations. The driving voltages of these devices increase with dopant concentrations, consistent with earlier reports that iridium complexes behave as carrier traps in devices. ${ }^{18} \mathrm{At}$ the lowest doping concentration of 0.18 wt \%, the EL spectrum mainly originates from the triplet emission of complex 1, accompanied by a minor contribution from the host emission (not shown here). Among various blends with complex $\mathbf{1}$, the best device performance was achieved at 1.8 wt \% (Figure 4b), which rendered a turn-on voltage of 9.4 $\mathrm{V}\left(\right.$ at $\left.1 \mathrm{~cd} / \mathrm{m}^{2}\right)$ and reached the maximum brightness of 7750 $\mathrm{cd} / \mathrm{m}^{2}$ at a driving voltage of $21 \mathrm{~V}$ and with CIE coordinates of $(0.64,0.31)$. Figure 5 shows external quantum efficiency and luminous efficiency, respectively, as a function of the current density of the device at a doping concentration of $1.8 \mathrm{wt} \%$. The maximum external quantum efficiency was shown to be $3.15 \% \mathrm{ph} / \mathrm{el}$ at a current density of $67.4 \mathrm{~mA} /$ $\mathrm{cm}^{2}$ with a brightness of $1751 \mathrm{~cd} / \mathrm{m}^{2}$. The device quantum efficiency remained at a relatively high value up to a driving current of $370 \mathrm{~mA} / \mathrm{cm}^{2}$. A further increase in doping concentration to $5.3 \mathrm{wt} \%$ led to a decrease in the external

(18) Chen, F.-C.; Chang, S. C.; He, G.; Pyo, S.; Yang, Y.; Kurotaki, M.; Kido, J. J. Polym. Sci., Part B: Polym. Phys. 2003, 41, 2681. 


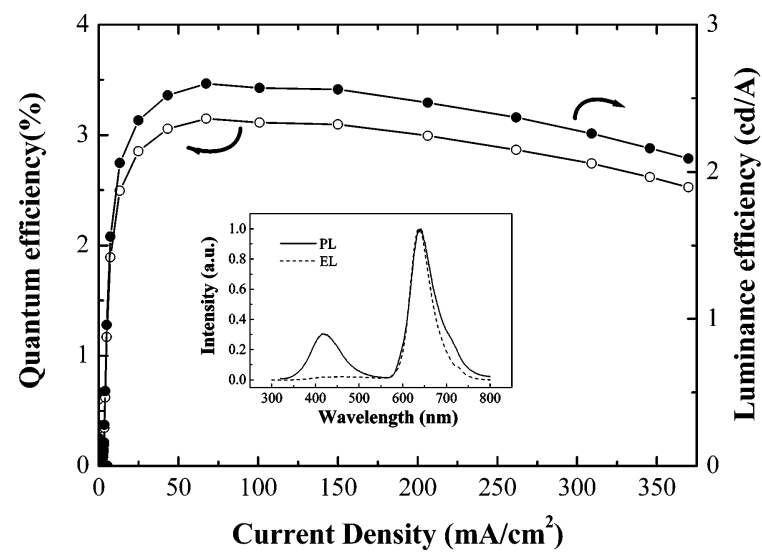

Figure 5. External quantum efficiency and luminous efficiency versus current density of the device with 1.8 wt $\%$ of $\mathbf{1}$ as the dopant emitter. Inset: PL and EL spectra recorded at a driving voltage of $21 \mathrm{~V}$.

quantum efficiency $(2.11 \% \mathrm{ph} / \mathrm{el})$ and brightness (1102 cd/ $\mathrm{m}^{2}$ at $67.4 \mathrm{~mA} / \mathrm{cm}^{2}$ ). This decrease might result from the concentration quenching and triplet - triplet annihilation. ${ }^{\text {la, } 19}$ We also studied PL spectra of the polymer blends. At the doping concentration of $1.8 \mathrm{wt} \%$, there was still a significant contribution of emission from the host material (the inset of Figure 5). At a doping concentration of $5.3 \mathrm{wt} \%$, the energy transfer was nearly complete and the PL was mainly from complex 1; however, the PL intensity was slightly decreased comparing with that at a concentration of $1.8 \mathrm{wt} \%$. This result is consistent with the concentration quenching ${ }^{20}$ and again indicates that the decrease in the external quantum efficiency at a doping concentration of $5.3 \mathrm{wt} \%$ might be a result of concentration quenching.

Since the PVK - PBD host exhibits an emission maximum at $420 \mathrm{~nm}$, there is a substantial overlap between the emission of the host and the spin-allowed MLCT absorption of $\mathbf{1}$. Accordingly, rapid Forster energy transfer between host and complex 1 is expected. The inset of Figure 5 shows the corresponding PL and EL spectra at the doping concentration of $1.8 \mathrm{wt} \%$ and a driving voltage of $21 \mathrm{~V}$. It should be noted that, despite the contribution of the PL spectrum from the host material, the corresponding EL spectrum was dominated by the triplet excited states of $\mathbf{1}$ with an emission peak wavelength at $640 \mathrm{~nm}$. The result strongly supports the supposition that both Forster energy transfer and direct charge-trapping/recombination at the iridium metal centers are responsible for the observed EL. ${ }^{20}$

\section{Discussion}

Tuning of the Emission Properties. Having gathered the above information, in combination with the reports in the literature (vide infra), in this section, we elaborate on the strategies of tuning the emission property in a systematic manner.

Cyclometalated $\operatorname{Ir}(\mathrm{ppy})_{3}$ has been extensively applied in fabricating green organic light-emitting and electrochemi-

(19) Gong, X.; Ostrowski, J. C.; Bazan, G. C.; Moses, D.; Heeger, A. J.; Liu, M. S.; Jen, A. K.-Y. Adv. Mater. 2003, 15, 45.

(20) Guo, T.-F.; Chang, S.-C.; Yang, Y.; Kwong, R. C.; Thompson, M. E. Org. Electron. 2000, 1, 15.
Scheme 2
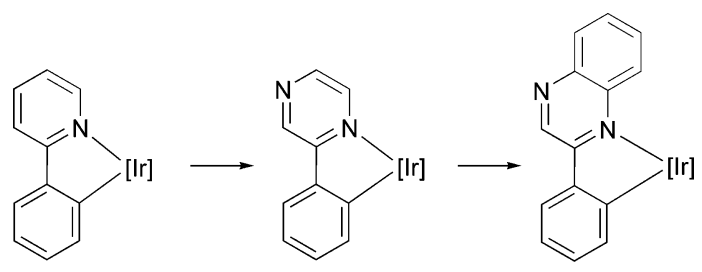

luminescent devices, ${ }^{21}$ while the strong emission occurring at $\lambda_{\max } 514 \mathrm{~nm}$ is believed to originate from the triplet excited states possessing both intraligand $\pi \pi^{*}$ and metal-to-ligand charge-transfer characters (MLCT). ${ }^{22}$ It is thus anticipated that tuning the emission to the red can be qualitatively achieved by lowering the energy level of either $\pi \pi^{*}$ or MLCT states of the iridium derivatives. The results of MO calculations on group 3 metal-8-quinolinato chelates ${ }^{23}$ as well as the boron pyridyl benzimidazole complexes ${ }^{24}$ lead us to propose that LUMO and HOMO of the cyclometalated ligands in the $\operatorname{Ir}(\mathrm{ppy})_{3}$ type of complexes are mainly located at the neutral part and the negatively charged side of the ligands, respectively. This delineation is also supported by the recently published, time-dependent density functional theory (TDDFT) calculation on Ir cyclometalated complexes. ${ }^{25}$ Accordingly, as shown in Scheme 2, replacement of one $\mathrm{CH}$ group at the pyridyl fragment by an electronegative nitrogen atom would give a pyrazine-substituted ligand fragment and display a significantly decreased LUMO energy level. Conversely, the HOMO of this complex, which is mainly located at the relatively electron rich phenyl group of the cyclometalated ligand or the $\mathrm{d} \pi$ states of the iridium atom, remains unchanged. Thus, such an atom substitution at the cyclometalated ligand will cause an appreciable reduction of the energy gap for the expected ${ }^{3} \pi \pi^{*}$ and ${ }^{3}$ MLCT emission. Further attachment of an extra aromatic ring into the ligand $\pi$ framework, e.g. using quinoxaline to replace the hypothetical pyrazine fragment, should elongate the overall $\pi$-conjugation, giving a further decrease of the energy gap. Therefore, continuously tuning the emission to the red can be rationalized.

In fact, the dpqx-based complex 1 shows a dark red emission at $\lambda_{\max } 642 \mathrm{~nm}$, which has been tuned much closer

(21) (a) Baldo, M. A.; Lamansky, S.; Burrows, P. E.; Thompson, M. E.; Forrest, S. R. Appl. Phys. Lett. 1999, 75, 4. (b) Tsutsui, T.; Yang, M.-J.; Yahiro, M.; Nakamura, K.; Watanabe, T.; Tsuji, T.; Fukuda, Y.; Wakimoto, T.; Miyaguchi, S. Jpn. J. Appl. Phys. 1999, 38, L1502 (c) Adachi, C.; Baldo, M. A.; Forrest, S. R.; Thompson, M. E. Appl. Phys. Lett. 2000, 77, 904. (d) Bruce, D.; Richter, M. M. Anal. Chem. 2002, 74, 1340 .

(22) (a) Sprouse, S.; King, K. A.; Spellane, P. J.; Watts, R. J. J. Am. Chem. Soc. 1984, 106, 6647. (b) Wilde, A. P.; King, K. A.; Watts, R. J. J. Phys. Chem. 1991, 95, 629. (c) Colombo, M. G.; Brunold, T. C.; Riedener, T.; Guedel, H. U.; Fortsch, M.; Buergi, H.-B. Inorg. Chem. 1994, 33, 545.

(23) (a) Chen, C. H.; Shi, J. Coord. Chem. Rev. 1998, 171, 161. (b) Curioni, A.; Boero, M.; Andreoni, W. Chem. Phys. Lett. 1998, 294, 263. (c) Anderson, S.; Weaver, M. S.; Hudson, A. J. Synth. Met. 2000, 111112, 459. (d) Sapochak, L. S.; Benincasa, F. E.; Schofield, R. S.; Baker, J. L.; Riccio, K. K. C.; Fogarty, D.; Kohlmann, H.; Ferris, K. F.; Burrows, P. E. J. Am. Chem. Soc. 2002, 124, 6119.

(24) (a) Liu, S.-F.; Wu, Q.; Schmider, H. L.; Aziz, H.; Hu, N.-X.; Popovic, Z.; Wang, S. J. Am. Chem. Soc. 2000, 122, 3671. (b) Liu, Q.; Mudadu, M. S.; Schmider, H.; Thummel, R.; Tao, Y.; Wang, S. Organometallics 2002, 21, 4743.

(25) Hay, P. J. J. Phys. Chem. A 2002, 106, 1634.

1350 Inorganic Chemistry, Vol. 44, No. 5, 2005 
to the dark red region. To counterbalance the excessive red shift, a rational design is to lower the HOMO of the cyclometalated ligand by replacing the phenyl fragment with a 4-fluorophenyl substituent. As predicted, the corresponding 4-fluorophenyl-substituted dfqx complex 2 exhibited a redorange emission at $\lambda_{\max }=630 \mathrm{~nm}$, supporting our proposed principle. Moreover, it has been reported that the replacement of one ppy ligand in the trisubstituted derivative $\operatorname{Ir}(\mathrm{ppy})_{3}$ with a bidentate ancillary ligand (LX) afforded mixed-ligand complexes (ppy) $\operatorname{Ir}(\mathrm{LX})$, where $\mathrm{LX}=$ acetylacetonate (acac), $\mathrm{N}$-methylsalicyliminate (sal), and picolinate (pic) ${ }^{26}$ In these mixed-ligand complexes, despite the emissions retaining the main characteristics of parent complex $\operatorname{Ir}(\mathrm{ppy})_{3}$, a minor dependence on the emission peak wavelength was also noted, which varies according to the nature of the ancillary ligand LX. For instance, the observed emission $\lambda_{\max }$ changes according to an order of pic $<$ sal $\sim$ acac, which is proportional to their electron donor strengths, resulting in a reduction of the energy gap. Accordingly, we can select the third ancillary ligands from the electron-deficient pyrazole (fppz)H and triazole (fppz)H or the electron-rich pyrazole (bppz) $\mathrm{H},{ }^{27}$ in an attempt to reach a saturated red emission. As the donor strengths are expected to follow a qualitative trend of fptz $<\mathrm{fppz}<\mathrm{bppz}$, we are not surprised that complex 3 displays the most blue-shifted emission signal. Conversely, complexes $\mathbf{1}$ and $\mathbf{4}$ show the best performance toward the saturated red among all the iridium metal complexes applied in this study.

Moreover, albeit not so well engineered, a qualitative trend of color tuning can sporadically also be found in the literature. Thompson and co-workers have reported a series of $\operatorname{Ir}$ complexes $(\mathrm{C} \wedge \mathrm{N})_{2} \operatorname{Ir}(\mathrm{LX})$, where $\mathrm{C} \wedge \mathrm{N}$ denotes various cyclometalated ligands such as phenyl pyridine (ppy), benzothiazole (bt), and benoxazole (bo) and LX is the $\beta$-diketonate ligand (Figure 6). ${ }^{17}$ The respective emission data make us to conclude that substitution of the parent phenylpyridine ligand (ppy) with the phenylbenzothiazole (bt) ligand caused a bathochromic shift of emission wavelengths from 516 to $557 \mathrm{~nm}$ due to the higher polarizibility and basicity of the sulfur atom. ${ }^{28}$ Certainly, the contribution from the extended aromatic $\pi$ system on the benzothiazole ligand cannot be completely ignored in accounting for the observed red shifting. Further increasing the degree of ligand $\pi$ conjugation can possibly be done by replacing the phenyl with a 1-naphthyl group, as observed in assembling the $\alpha \mathrm{bsn}$ ligand. This manipulation is expected to shift the emission wavelength further toward the red, giving a strong PL emission at $606 \mathrm{~nm}$. It is also notable that the 2-naphthyl group in $\beta$ sbsn acts less effectively than the 1-naphthyl group in $\alpha$ bsn, resulting in an orange emission with $\lambda_{\max }$ at 594

(26) Lamansky, S.; Djurovich, P.; Murphy, D.; Abdel-Razzaq, F.; Kwong, R.; Tsyba, I.; Bortz, M.; Mui, B.; Bau, R.; Thompson, M. E. Inorg. Chem. 2001, 40, 1704.

(27) (a) Cheng, C.-C.; Yu, W.-S.; Chou, P.-T.; Peng, S.-M.; Lee, G.-H.; Wu, P.-C.; Song, Y.-H.; Chi, Y. Chem. Commun. 2003, 2628. (b) Wu, P.-C.; Yu, J.-K.; Song, Y.-H.; Chi, Y.; Chou, P.-T.; Peng, S.-M.; Lee, G.-H. Organometallics 2003, 22, 4938.

(28) Zollinger, H. Color Chemistry: Syntheses, Properties and Applications of Organic Dyes and Pigments, 2nd ed.; VSH: Weinheim, Germany, 1991.

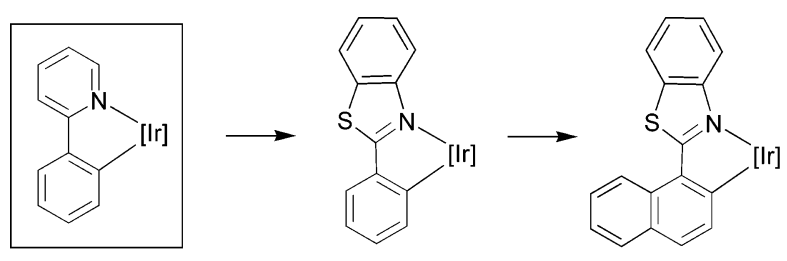

ppy; $516 \mathrm{~nm} \quad$ bt; $557 \mathrm{~nm} \quad \alpha b s n, 606 \mathrm{~nm}$

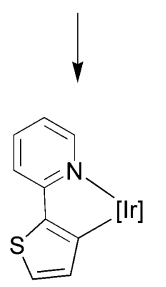

thp, $562 \mathrm{~nm}$
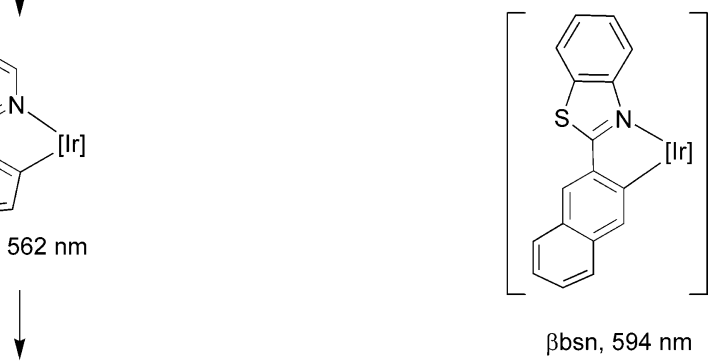

ßbsn, $594 \mathrm{~nm}$

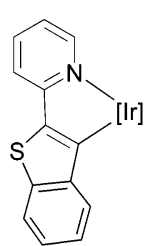

btp, $612 \mathrm{~nm}$

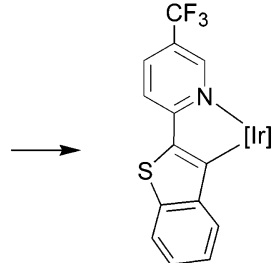

fbtp, $617 \mathrm{~nm}$
Figure 6. Basic molecular design and emission $\lambda_{\max }$ of iridium complexes $(\mathrm{C} \wedge \mathrm{N})_{2} \operatorname{Ir}(\mathrm{acac})$, where symbol [Ir] indicates the missing molecular fragment $(\mathrm{C} \wedge \mathrm{N}) \operatorname{Ir}(\mathrm{acac})$. The ligand abbreviations are named according to those that first appeared in the literature.

$\mathrm{nm}$, accompanied by a slight decrease in the luminescent quantum efficiency from 0.22 to 0.16 . Although the exact nature of the ligand orientation effect remains unclear at this stage, the results imply that the orientation of $\pi$ conjugation would exert a large effect on the photophysical properties of the phosphorescent complexes. On the other hand, an electron-donating thiophene group (thp) can be selected to replace the phenyl substituent of ppy ligand to induce a similar red shift to $562 \mathrm{~nm}$. Further extending the $\pi$ conjugation to the thp ligand as well as the insertion of an extra electron withdrawing $\mathrm{CF}_{3}$ group at the 4-position of the pyridyl group would result an additional red shift, giving rise to emission peak wavelengths at 612 and $617 \mathrm{~nm},{ }^{29}$ as observed for the btp and fbtp complexes shown in Figure 6 . Finally, although it was not explicitly shown by the available data, these sulfur-containing materials may show slightly lower emission quantum yields related to complexes possessing no sulfur substituent. This result, to a certain extent, could be attributed to the thermal population of the proximal $\mathrm{n} \pi^{*}$ excited state, which tends to give a less effective radiative transition probability.

Researchers have also directed their attention to fine-tuning the emission color of another class of iridium complexes,

(29) (a) Okada, S.; Iwawaki, H.; Furugori, M.; Kamatani, J.; Igawa, S.; Moriyama, T.; Miura, S.; Tsuboyama, A.; Takiguchi, T.; Mitutani. H. SID Symp. Dig. 2002, 1360. (b) Chen, X.; Liao, J.-L.; Liang, Y.; Ahmed, M. O.; Tseng, H. E.; Chen, S. A. J. Am. Chem. Soc. 2003, 125, 636. (c) Adachi, C.; Baldo, M. A.; Forrest, S. R.; Lamansky, S. Thompson, M. E.; Kwong, R. C. Appl. Phys. Lett. 2001, 78, 1622. 
Hwang et al.

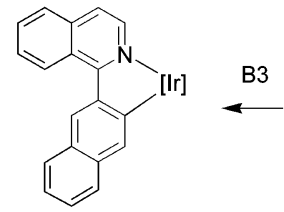

2-niq; $633 \mathrm{~nm}$

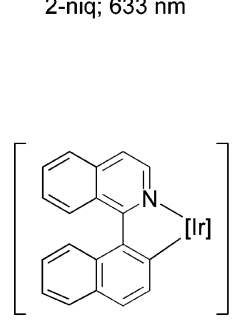

1-niq; $680 \mathrm{~nm}$

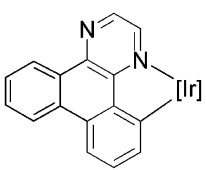

$\mathrm{dbq} ; 618 \mathrm{~nm}$

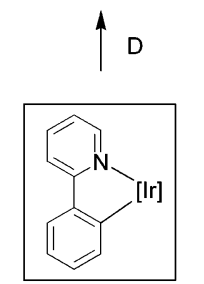

ppy; $516 \mathrm{~nm}$

$\downarrow B 1$

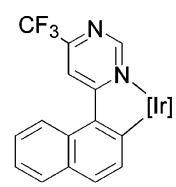

napm; 620 nm

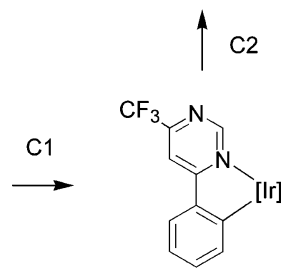

ppm; $580 \mathrm{~nm}$

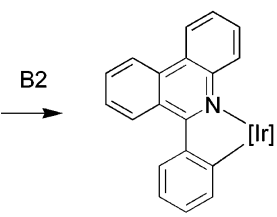

nazo; $625 \sim 638 \mathrm{~nm}$
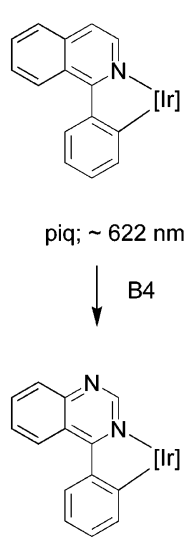

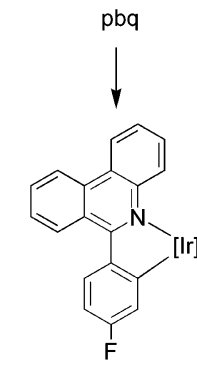

F-pbq; $631 \mathrm{~nm}$

Figure 7. Basic molecular design and emission $\lambda_{\max }$ of iridium complexes $(\mathrm{C} \wedge \mathrm{N})_{3} \operatorname{Ir}$ or $(\mathrm{C} \wedge \mathrm{N})_{2} \operatorname{Ir}(\mathrm{LX})$, where symbol [Ir] indicates the missing molecular fragment $(\mathrm{C} \wedge \mathrm{N})_{2} \operatorname{Ir}$ or $(\mathrm{C} \wedge \mathrm{N}) \operatorname{Ir}(\mathrm{LX})$. The ligand abbreviations are named according to those that first appeared in the literature.

for which the cyclometalated $\mathrm{C} \wedge \mathrm{N}$ ligands of $\operatorname{Ir}(\mathrm{C} \wedge \mathrm{N})_{3}$ or $\operatorname{Ir}(\mathrm{C} \wedge \mathrm{N})_{2}(\mathrm{LX})$ show no sulfur substituents and $\mathrm{LX}$ is $\beta$-diketonate or other nitrogen-containing chelate ligand. ${ }^{30}$ On one hand, as indicated in Figure 7, one simple strategy is to replace the pyridine fragment of ppy ligand with a 2-quinolinyl group. Orange emission at $597 \mathrm{~nm}$ is thus observed by extending the $\pi$ conjugation (see route $\mathrm{A}$ in Figure 7). ${ }^{12}$ On the other hand, a more effective approach is to replace the pyridine fragment of the ppy ligand with a 1 -isoquinoline group. Using this methodology, complexes of formula $\operatorname{Ir}(\mathrm{piq})_{3}$ or $\operatorname{Ir}(\mathrm{piq})_{2}$ (acac) were synthesized, both revealing intense red emissions centered at $\sim 622 \mathrm{~nm}$ (route B1). ${ }^{31}$ Further extending the $\pi$ system via selecting the benzoquinoline yields the corresponding pbq complex with a rather dark red color (route B2). As a result, application of 4- $\mathrm{FC}_{6} \mathrm{H}_{4}$ group is necessary to blue shift the emission wavelength toward $631 \mathrm{~nm}$, as has been demonstrated in

(30) Wang, Y.; Herron, N.; Grushin, V. V.; LeCloux, D.; Petrov, V. Appl. Phys. Lett. 2001, 79, 449

(31) (a) Tsuboyama, A.; Iwawaki, H.; Furugori, M.; Mukaide, T.; Kamatani, J.; Igawa, S.; Moriyama, T.; Miura, S.; Takiguchi, T.; Okada, S.; Hoshino, M.; Ueno, K. J. Am. Chem. Soc. 2003, 125, 12971. (b) Jaing, C.; Yang, W.; Peng, J.; Xiao, S.; Cao, Y. Adv. Mater. 2004, 16, 537.

complexes possessing the F-pbq ligand..$^{32}$ This manipulation is consistent with a two-step synthetic scheme incorporating an extension of $\pi$-conjugation, followed by lowering of the HOMO energy level using an electronegative $F$ atom. Moreover, when the isoquinoline fragment is targeted to link with a 1-naphthyl or 2-naphthyl substituent (route B3), red and dark-red emission at 633 and $680 \mathrm{~nm}$ were eventually observed due to the extension of $\pi$ conjugation. ${ }^{33}$ The large difference of $47 \mathrm{~nm}$ in these emission peaks is rationalized by the presence of two distinctive naphthyl ligand orientations, in which the electronic transition dipole moment could be markedly different. An additional example involves the conversion from isoquinoline to quinazoline (route B4), for which the extra nitrogen atom on the ligand skeleton is expected to exert a large bathochromic effect on the emission wavelength via lowering of the LUMO energy level. ${ }^{34}$ Phenylquinazoline appears to be an accessible and highly reactive cyclometalated ligand, which gives rise to required iridium complexes with a red emission $(625-638 \mathrm{~nm})$ after incorporating a 2-pyridylpyrazolate type of ligand, which is comparably more electron deficient compared with diketonate chelating ligands while completing the octahedral ligand arrangement required for Ir metal complexes.

Other color-tuning principles have also been documented in the literature. For example, routes $\mathrm{C} 1$ and $\mathrm{C} 2$ indicate that substitution of pyrimidine for pyridine exerts a similar effect of lowering the LUMO. A further red shift is observed when employing a 1-naphthyl group to replace the phenyl fragment, of which the highest energy emission $\lambda_{\max }$ occurs at $618 \mathrm{~nm}$, suitable for fabricating the saturated red color OLEDs. Note that further red shifting is commonly observed after mixing with the polymer host matrix. ${ }^{35}$ In contrast, route $\mathrm{D}$ represents a unique strategy, in which introducing an electronegative nitrogen atom and enlarging the $\pi$ delocalization across the whole ligand $\pi$ system have been achieved in one step using an aromatic heterocycle, dibenzo[f,h]quinoxaline. ${ }^{36}$ Devices based on this Ir complex have been made with orange red emission at $\sim 610 \mathrm{~nm}$, accompanied by an exceedingly high brightness of $58100 \mathrm{cdm}^{-2}$ and excellent current and power illumination efficiencies of 26.2

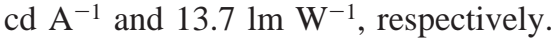

Nevertheless, several less successful examples of color tuning have also been documented in the literature. Parts of these articles described the use of aldehyde-,${ }^{37}$ perfluorophenyl-, ${ }^{38}$ and even fluorene-modified phenylpyridine-based

(32) Su, Y.-J.; Huang, H.-L.; Li, C.-L.; Chien, C.-H.; Tao, Y.-T.; Chou, P.-T.; Datta, S.; Liu, R.-S. Adv. Mater. 2003, 15, 884

(33) Yang, C.-H.; Tai, C.-C.; Sun, I.-W. J. Mater. Chem. 2004, 14, 947.

(34) Song, Y.-H.; Yeh, S.-J.; Chen, C.-T.; Chi, Y.; Liu, C.-S.; Yu, J.-K.; Hu, Y.-H.; Chou, P.-T.; Peng, S.-M.; Lee, G.-H. Adv. Funct. Mater. 2004, 14, 1221.

(35) Niu, Y.-H.; Chen, B.; Liu, S.; Yip, H.; Bardecker, J.; Jen, A. K.-Y.; Kavitha, J.; Chi, Y.; Shu, C.-F.; Tseng, Y.-H.; Chien, C.-H. Appl. Phys. Lett. 2004, 85, 1619.

(36) Duan, J.-P.; Sun, P.-P.; Cheng, C.-H. Adv. Mater. 2003, 15, 224.

(37) Beeby, A.; Bettington, S.; Samuel, I. D. W.; Wang, Z. J. Mater. Chem. 2003, 13, 80 .

(38) Tsuzuki, T.; Shirasawa, N.; Suzuki, T.; Tokito, S. Adv. Mater. 2003 , $15,1455$. 
ligands. ${ }^{19,39}$ It is notable that all these functional groups are unable to exert further reduction in the HOMO/LUMO gap to fulfill the saturated red emission. As a result, the corresponding emission wavelength spans only a narrow range between yellow and orange, despite some of them showing rather interesting and marvelous characteristics, such as the enhancement of thermal stability, improved electrontransporting properties, or even a higher glass transition temperature so that the smooth film can be directly obtained from the amorphous state.

\section{Conclusion}

In summary, we report detailed syntheses and electrochemical and photophysical properties of four red-emitting iridium metal complexes using the cyclometalated quinoxaline ligands as well as one nitrogen chelate ligand, such as the pyridylpyrazolate or -triazolate. These complexes exhibit high emission quantum yields and short phosphorescence radiative lifetimes in the range of several microseconds that are suitable for serving as red-emitting materials for PLED

(39) (a) Ostrowski, J. C.; Robinson, M. R.; Heeger, A. J.; Bazan, G. C. Chem. Commun. 2002, 784. (b) Gong, X.; Lim, S.-H.; Ostrowski, J. C.; Moses, D.; Bardeen, C. J.; Bazan, G. C. J. Appl. Phys. 2004, 95, 948. and OLED applications. By executing our design strategy, we have gained knowledge and developed a semiquantitative method of achieving the much-needed red emission. This method incorporates the utilization of two cyclometalated ligands with extended $\pi$ system and one extra electron negative nitrogen atom to counterbalance the energy gap suited to the saturated red emission, which is complementary to the results first reported by Thompson and co-workers. ${ }^{12}$ Simple PLED devices were also prepared to evaluate their practical potentials, for which good device performance has been successfully achieved using complex $\mathbf{1}$ at lower dopant concentrations, demonstrating a rare example of highly efficient $\operatorname{Ir}(\mathrm{III})$-based light-emitting devices with saturated red emission.

Acknowledgment. We thank the National Science Council for the support (Grants NSC 93-2113-M-007-012 and NSC 93-ET-7-007-003). Special thanks go to Prof. C.-H. Cheng and Dr. J.-P. Duan for their assistance on preparation of PLED devices and recording the electroluminescent data.

Supporting Information Available: An X-ray crystallographic data file (CIF) for complex 1. This material is available free of charge via the Internet at http://pubs.acs.org.

IC0489443 